\title{
ПРОБЛЕМА ПРАВОВОЇ ПРИРОДИ ЦИВІЛІСТИЧНО-ЗЕМЕЛЬНОЇ «ТРІАДИ» В КОНТЕКСТІ ЄДНОСТІ ДОЛІ ЗЕМЕЛЬНОї ДІЛЯНКИ ТА ЗВЕДЕНИХ НА НІЙ ОБ'ЄКТІВ
}

Шматько Г. І.

У науковій статті автором запропонована спроба переосмислення й перегляду сутності категорій власності, нерухомості та земельної ділянки як індивідуальних один від одного й водночас нерозривно пов'язаних елементів людського буття, економіки, правового життя суспільства. Розкриття соціальної та правової природи зазначених категорій у контексті об'єднання в цивілістично-земельну «тріаду» дозволяє продовжувати теоретичний і практичний розвиток у зв'язку неминучого стикання гуманітарних та природничих наук.

Ключові слова: категорія, цивільне право, земельне право, земельна ділянка, нерухомість, річ, земля, будівля, зведений об'єкт.

В научной статье автором предложена попытка переосмысления и пересмотра сущности категорий собственности, недвижимости и земельного участка как индивидуальных друг от друга и в то же время неразрывно связанных элементов человеческого бытия, экономики, правовой жизни общества. Раскрытие социальной и правовой природы указанных категорий в контексте объединения в цивилистическо-земельную «триаду» позволяет продолжать теоретическое и практическое развитие в связи неизбежного соприкосновения гуманитарных и естественных наук.

Ключевые слова: категория, гражданское право, земельное право, земельный участок, недвижимость, вещь, земля, здание, возведенный объект.

Shmatko H. I. Problem of legal nature of civilistic and land "triad" in the context of superficies solo cedit principles

This scientific article offers an attempt by the author to rethink and reconsider the essence of the categories of property, real estate and land as individuals and at the same time inextricably linked elements of human existence, economy, legal life of society. The disclosure of the social and legal nature of these categories in the context of the unification into a "triad" of civil-land relations allows for the continuation of theoretical and practical development in connection with the inevitable clash of the humanities and natural sciences. The only thing that is definitely recognized as real estate is land, namely land that is subject to special protection by the state. The provisions of the legislation of some countries do not provide for the possibility of extending real estate regime to movable property. In different countries, the concept of "real estate" is interpreted differently, the law of some defines real estate through the rights to it, others - through physical properties (ability to move, the ability to use for its intended purpose, etc.). Since in civil circulation the object of law (thing) actually merges with the subjective right to it, we will consider in general terms the main features and properties of these real estate objects. As a result of generalization at the theoretical level of land plot together with all real estate under it and above it. Everything that cannot be moved relative to the earth without significant

(с) Шматько Г. І., 2020 damage also applies to land itself. Self-awareness of the owner, which is inherent in the psychology of personality, is possible only in relation to others, because the perception of "one's" is possible in the presence of "others" in the process of interaction with other similar individual possession. Today Ukraine has moved to a modern model of management, the state promotes the formation, development and renewal of real estate market, changes and improves land relations, promotes the protection and defense of property rights as the most important and inalienable quality and human rights.

Key words: category, civil law, land law, land plot, real estate, thing, land, building, consolidated object.

Постановка проблеми та іï актуальність. Становлення кожної держави залежить від багатьох системотворчих чинників, котрі задають їі напрями розвитку. Одним із найважливіших «Життєвих» чинників системи державного устрою $€$ національна економіка, економічний сектор держави, розбудова й модернізація котрого $\epsilon$ пріоритетною метою створення добробуту всередині країни та формування й налагодження міцних зв'язків з іншими державами ззовні. Україна сьогодення перейшла до сучасної моделі господарювання, держава сприяє формуванню, розвитку та оновленню ринку нерухомості, змінює та вдосконалює земельно-правові відносини, сприяє охороні та захисту права власності як найважливішої й невід'ємної якості та права людини. Ця «тріада» категорій $є$ об'єктом численних наукових дискусій, поглядів, світобачень. Зміни, які людина вносить у ці поняття, спричинюють наслідки майбутньої трансформації економічного, політичного та національного життя кожної нації та народів усієї планети. Зазначена проблематика $\epsilon$ вкрай актуальною, адже без розуміння сутності процесів та природи вказаних понять людство не зможе рухатись шляхами розвитку побудови симбіозу правової держави та громадянського суспільства.

Метою статті $\epsilon$ спроба визначення та осмислення нормативно-правової природи та земельно-правового регулювання цивілістично-земельних категорій у контексті єдності правової долі земельної ділянки та зведених на ній об'єктів.

Теоретичною основою статті стали наукові праці вчених-фахівців у галузі аграрного, земельного, природоресурсного та екологічного права Одеської правової школи, зокрема таких, як Н. Гавриш, І. Каракаш, О. Погрібний, В. Сидор, Т. Харитонова, та інших. Висунуті питання певною мірою досліджувались такими визнаними вченими, як В. Андрейцев, Г. Балюк, О. Бондарь, О. Браніцький, Д. Бусуйок, Ю. Дрозд, А. Дудін, П. Кулинич, Л. Лейба, Р. Машуков, А. Мірошніченко, Н. Мисник, А. Мінаєва, О. Пащенко, В. Семчик В. Носік, Н. Титова, М. Шульга, тощо. Серед науковців, праці яких стосуються економічної природи нерухомості 


\section{Проблеми цивільного та господарського права}

та особливостей їі ринкового обігу, виділено таких, як А. Асаул, Л. Бєлих, А. Брижань, Н. Внукова, В. Геєць, І. Геллєр, О. Каплій, О. Кашенко, О. Мірошниченко, В. Онищенко, Н. Павліха, В. Павлов, К. Паливода, М. Федотова, та ін. Особливо варто виділити науковий уклад наууковців, завдяки працям котрих стало можливим написання цієї статті.

Виклад основного матеріалу. Категорія власності ввійшла в повсякденне вживання задовго до появи наукових теорій і концепцій про неї. Термін «власність» у гуманітарних дослідженнях уживається в багатьох значеннях й аспектах, уявлення про яку формувалось протягом тисячоліть, але розуміння і тлумачення власності все ще залишаються спірними і сприймаються неоднаково. В українській, російській та зарубіжній науковій літературі проблеми власності $\epsilon$ достатньо дослідженими, проте вони досі дискусійні. Висування відносин власності на пріоритетне місце соціальної думки в сучасному українському суспільстві пояснюється здійсненням їх докорінного перетворення і радикального реформування, з якими пов'язуються першорядні матеріальні інтереси людини й суспільства.

У повсякденній свідомості, котра формується під впливом процесів звичайної життєдіяльності людини, розуміння власності пов'язується із зовнішніми предметами неживого світу і сприймається як ставлення людей до належних їм речей. Усвідомлення власності в людино-речовому розумінні видається як належність речей, предметів або об'єктів зовнішнього світу певним особам. Така належність надає конкретним особам можливості відповідного впливу на ці об'єкти з метою реалізації певних інтересів і задоволення необхідних потреб. Тому особистісно-речові зв'язки формуються передусім на індивідуальному чи сімейному рівнях, а в майбутньому переростають до вищої узагальненої свідомості. На звичайному рівні формується уявлення про існування якогось фактичного зв'язку між суб'єктами-власниками та об'єктами-речами, який виникає у процесі задоволення людиною своїх матеріальних і духовних потреб.

Ще в період європейського середньовіччя зустрічалось чимало прикладів, коли відторгнення від «своєі землі» призводило до втрати статусу особистості. Видимі ознаки особистісно-речових зв'язків у сучасних умовах можна охарактеризувати як односторонні суб' $є$ ктно-об'єктні зв'язки, котрі складаються, наприклад, у відносинах громадян, юридичних осіб, виробничих колективів, регіональних спільнот чи суспільства загалом до земельних, гірничих, водних, лісових та інших природних ресурсів, засобів виробництва, предметів споживання, об'єктів обміну тощо. Прискіпливий розгляд відносин власників до належних їм об'єктів на буденному рівні дозволяє говорити про наявність певної психологічної прихильності фізичних осіб до матеріальних речей і предметів зовнішнього світу.

Панування людини над речами являє собою фактичне володіння над ними доти, доки вони в ії володінні. Водночас варто звернути увагу на те, що початкове усвідомлення себе відособленою особистістю як такою відбувається через сприйняття належності певних предметів конкретному індивідууму, який виокремлює себе від собі подібних, за допомогою володіння речами й об'єктами зовнішнього світу. Між тим особистісно-речовий аспект власності на повсякденному рівні був очевидним ще у стародавні часи. Це підтверджується в різних народів, наприклад, звичаями поховання померлих разом із їх речами [1, с. 431-432]

Проте категорія власності як ставлення людини до речей або предметів зовнішнього світу до матеріальних благ або природних багатств не може розглядатись тільки на відокремлено-індивідуальному рівні особистісно-речових зв'язків. Усвідомлення себе власником, що притаманно психології особистості, можливо тільки щодо інших, адже сприйняття «свого» можливе за наявності «чужого» у процесі взаємодії з іншими собі подібними індивідуумами. В умовах споживання предметів природи у відокремленому середовищі існування людини або в ії соціально ізольованому оточенні не можуть формуватись повноцінні відносини власності. До того ж людина не $\epsilon$ абсолютно вільною ані у природному, ані в соціальному середовищі, і як особистість поєднує в собі природні та соціальні обмеження. На підставі цього варто погодитись із $\epsilon$. Сухановим [2] у тому, що «власність одних людей чи їх колективів на майно нерозривно пов'язана з відчуженням цього майна від інших людей».

Аналізуючи наступні категорії, котрі входять у площину «власності» та безумовно $є$ об' єктами останньої, варто детальніше зупинитись на такому понятті, як річ, та провести особливості відмінностей нерухомості та земельної ділянки. Російський цивіліст К. Скловський влучно відзначив: «Вещь - не явление физики. Понятие вещи отсылает не к природе, а к человеку <...». У цьому сенсі річчю $€$ система певних якостей (властивостей) [3]. Але й у соціальних науках термін «річ» уживається в різних значеннях. Із філософського погляду річчю можна назвати відокремлений предмет матеріального світу, котрий має порівняно самостійне та усталене існування.

Безпосередньо термін «річ» у юридичному сенсі позначає насамперед поняття приватного (цивільного) права. Відповідно до ст. 179 Цивільного кодексу України [4] (далі - ЦКУ) річчю $\epsilon$ предмет матеріального світу, щодо якого можуть виникати цивільні права та обов'язки. Термін «можуть», на нашу думку, означає «можуть у принципі ». Тобто не може вважатись річчю як категорією цивільного права той фізичний феномен, щодо якого позитивне право не припускає виникнення цивільних прав та обов'язків. На певному етапі суспільного розвитку окремі предмети та явища не можуть бути піддані контролю та опануванню з боку людей. Отож щодо них не може виникнути цивільне право. У цивілістичній літературі зі складу речей часто виключають повністю вилучені з обігу предмети, тобто привласнені виключно державою (народом). Тут, як видається, «право власності» відповідного публічного суб'єкта розглядається як специфічна публічно-правова категорія

Отже, цивілістичне визначення поняття речі відсилає до прав на неї. Так, російський дослідник О. Латиєв [5] указує на тотожність понять «річ» та «об'єкт речового права». Речі у праві $\epsilon$ різновидом об'єктів прав та протистоять як об'єкт пізнання тощо, суб'єктам прав. У реальній дійсності поняттю «об'єкта права», так само як і поняттю «суб'єкта права», відсутні прямі відповідники. Це наукові правові абстракції, котрі мають найвищій рівень узагальнення, їх емпіричною основою $\epsilon$ безліч конкретних цінностей. Під час абстрагування 
відбувається сходження від конкретних позаправових феноменів до правових абстракцій «речей», «грошей», «прав» тощо. На вищому рівні ці абстракції узагальнюються в абстракцію «об'єктів прав». Чинне законодавство визначає рухомими ті речі, які можна вільно переміщувати у просторі (ч. 2 ст. 181 ЦКУ). До нерухомих речей належать земельні ділянки, а також об'єкти, розташовані на земельній ділянці, переміщення яких $\epsilon$ неможливим без їх знецінення та зміни їх призначення (ч. 1 ст. 181 ЦКУ). Окремою нормою закону до нерухомості віднесено підприємство як єдиний майновий комплекс (ст. 191 ЦКУ).

Режим нерухомої речі може бути поширений на інші речі, права на які підлягають державній реєстрації. Але про це має бути окрема законодавча вказівка, загальних положень кодексу про таку «можливість» недостатньо. Як видно, делімітація рухомих та нерухомих речей $\epsilon$ умовною. Нерухомі речі меншою мірою відповідають тому фізичному феномену, котрий $\epsilon$ їх «прототипом» (який сприймається безпосередньо через органи відчуття), аніж рухомі речі. Як економічна категорія, нерухомість - це особливий товар, а в повсякденному житті це поняття видається чимось зрозумілим кожному.

Проте юридичне визначення нерухомості відрізняється, воно детермінується особливостями економічного розвитку країни, історичними традиціями тощо. Під кутом зору юридичної техніки визначення нерухомості в позитивному праві здійснюється в такі найпоширеніші способи: шляхом прямого визначення переліку у відповідних правових нормах типів конкретних об'єктів, що належить вважати нерухомістю, або через визначення загального поняття та (або) ознак нерухомого майна [6, с. 823].

На думку Д. Розенберга, нерухоме майно, нерухомість - це реальна земельна та матеріальна власність, яка охоплює все матеріальне майно над поверхнею землі, під поверхнею або прикріплене до землі. Оксфордські вчені вважають, що нерухоме майно - це будь-яке майно, що складається із землі, будівель і споруд на ній [7].

На думку М. Кулагіна, за своєю природою майно $\epsilon$ нерухомим унаслідок його призначення або внаслідок предмета, належним до якого воно $\epsilon$. Водночас розуміння поняття «нерухомість», відповідно до змісту законодавства Росії, з початку минулого сторіччя $\epsilon$ ширшим і значно різниться; нерухомим майном за своїм визначенням є землі, угіддя, фабрики, заводи, будівлі, залізниці та порожні дворові місця [8, с. 112-113].

Унаслідок узагальнення на теоретичному рівні поняття «об'єкта нерухомості» розуміють земельну ділянку разом з усією нерухомістю, яка $\epsilon$ під нею й над нею; все те, що без значної шкоди не може бути переміщене щодо землі - стосується й самої земельної ділянки. Незважаючи на тривалість використання у світовій практиці терміна «нерухомість», суттєвих розбіжностей у його змісті не простежуємо. Всі визначення зведено до того, що до нерухомості відносять землю та все, що на ній $є$. Отже, можемо зробити висновок, що йдеться про землю й об'єкти, які з нею нерозривно пов'язані.

На сьогодні кожна держава, зважаючи на власні правові традиції та рівень розвитку суспільних відносин, самостійно визначає речі, які $\epsilon$ нерухомими або на які поширюється режим нерухомого майна. Такий під- хід до визначення поняття нерухомого майна в різних правових системах відображено в нормативно-правових актах, які регулюють приватноправові відносини, а тому одна й та сама річ може мати різний статус: в одних країнах може бути нерухомою, а в інших - рухомою.

Згідно із цивільним законодавством Російської Федерації, нерухомість - це земельні ділянки; ділянки надр, відокремлені водні об'єкти та все, що міцно пов'язане із землею, а зокрема - об'єкти, переміщення яких без значної шкоди їх призначенню неможливе (споруди, будинки, ліси, багаторічні насадження). За Цивільним кодексом Німеччини, до нерухомого майна віднесено землю та ії складові частини; споруди; речі, котрі міцно пов'язані із ґрунтом; насіння, якщо воно внесене в землю; продукти землі, поки вони пов'язані із ґрунтом; насадження й рослини (ст.ст. 94-96 Німецького цивільного укладу). Відповідно, схожі ознаки нерухомого майна містяться й у Цивільних кодексах Швейцарії, Італії (ст. 812), Японії (ст. 86).

Цивільний кодекс Франції поняття нерухомості розглядає у значно ширшому розумінні. До об'єктів нерухомого майна віднесено землю та пов'язані з нею споруди, урожай, ліси тощо; за її призначенням - машини, інструменти й сировина, яка використовується на підприємстві, сільськогосподарське знаряддя та худоба, хоча за своєю природою вони є рухомими. У випадку виділення цих нерухомостей зі складу господарства вони розглядаються як рухоме майно. Під поняття нерухомості також підпадають майнові права, котрі встановлено на неї. Відповідно до Цивільного кодексу Бразилії (ст. 43) 1920 р. нерухомими речами $є$ ґрунт із його поверхнею, природними багатствами, враховуючи дерева, плоди на корені, наземний простір і надра; те, що особа прикріпляє до землі на тривалий час, посіви в землі, будівлі та споруди, які не можуть бути переміщені без руйнування, переобладнання, розламування або завдання їм шкоди; все те, що власник відносить до нерухомості у зв'язку з використанням у промисловому виробництві, прикрашання або комфорту.

Цивільний кодекс Республіки Куба 1987 р. (ч. 2 ст. 46.1) визначає, що матеріальними речами може бути нерухоме майно чи особиста власність, розуміючи під нерухомим майном землю й інші речі, прикріплені до неї так надійно, що це унеможливлює користування ними чи їх використання за попереднім призначенням. Цивільний кодекс Португалії визначає, що нерухомістю окремі види майна будуть у разі нерозривного зв'язку із землею. На суттєво іншому підході ґрунтується законодавство США. Законом «Про ліцензування й реєстрацію нерухомого майна» (1980 р.) визначено, що нерухомим майном є будь-яке майнове право на землю або майно, яке розміщене на ній, незалежно від того, чи $\epsilon$ воно матеріальним або нематеріальним, умовним чи безумовним, або розміщене в межах Федерації чи будь-де в іншому місці, включно з орендним правом, строкові права й аналогічно визначені майнові права.

Дещо подібний підхід до визначення нерухомого майна застосовано в Торговельному й Цивільному кодексі Таїланду. У ст. 139 цього документа міститься таке трактування: «Нерухомим майном є земля, а також речі, надійно прикріплені до неї або які формують єдине ціле з нею. Нерухоме майно також уключає речові права, пов'язані із землею або речами, котрі формують із нею одне ціле». [9, с. 13-14]. 
Відповідно до ст. 5 Закону «Про державну реєстрацію речових прав на нерухоме майно та їх обтяжень» [10] до таких, окрім земельних ділянок, як основних нерухомих речей, належать:

1) житлові будинки, будівлі, споруди (ï окремі частини );

2) квартири;

3) житлові та нежитлові приміщення;

4) підприємства як єдині майнові комплекси.

Будинки, будівлі, споруди (далі узагальнено будівлі) - це окремі будівельні системи (земельні поліпшення), котрі знаходяться на землі, або над чи під землею (поверхнею), їх юридична доля пов'язана з юридичною долею відповідних земельних ділянок, що відображено у ст. 377 ЦКУ, 120 ЗКУ. На перший погляд, будівлі $є$ тими нерухомими речами, де їх правовий опис повною мірою кореспондує відповідному фізичному феномену. Дійсно, за загальним правилом, власник панує найвищою мірою над матеріальними конструкціями будівлі та всім «внутрішнім простором». Водночас ст. 349 ЦКУ наштовхує на думку, що право власності на нерухомість (зокрема, на будівлі) продовжує існувати після фізичного знищення об'єкту, аж до скасування запису про таке право за заявою самого власника. Проте ця норма $\epsilon$ неоднозначною.

Традиційно «основною» нерухомою річчю вважається земельна ділянка. Звичайно, вона (земельна ділянка - об'єкт нерухомості) $\epsilon$ також правовою абстракцією. Ділянки як об'єкти цивільних прав формуються шляхом визначення площі, меж та внесення інформації до Державного земельного кадастру. Вони вважаються сформованими з моменту присвоєння кадастрового номера.

Межі сформованої земельної ділянки виносяться в натуру (на місцевість), після чого вона реєструється в кадастрі. Водночас межі ділянок не завжди закріплюються на місцевості фізично (межовими знаками, так званими «стовпчиками»). Це свідчить про «допоміжний» характер процедури встановлення на місцевості меж ділянки, як певної стадії формування ділянки як об'єкта прав, для ії «запуску» (включення) в ринковий обіг, вона також виконує функцію забезпечення кращого врахування прав «суміжників», уникнення помилок під час установлення меж тощо. «Земля», навіть позначена межовими знаками, - це ще не річ, не об'єкт прав, аж до формування окремої земельної ділянки, за допомогою відповідних юридичних дій. Це підкреслює абстрактність цієї особливої нерухомої речі.

Сама ідея закріплення меж матеріальними предметами (межовими знаками) зумовлена бажанням об'єктивізувати та індивідуалізувати абстракцію земельної ділянки, той простір, який уявляє собою конструкція «земельна ділянка». Проте за правом суб'єктові все одно належить земельна ділянка як правова абстракція. Як відомо, земельні ділянки мають різний правовий режим, що теж $\epsilon$ юридичним поняттям. Право перетворює (модифікує) природні властивості «землі» як природного об'єкта, частини екосистеми, у відповідний правовий режим, у сукупність прав та обов'язків, фактичних (реальних) можливостей.
Висновки. Підбиваючи підсумки щодо розглянутої «тріади», можна казати про неоднозначність суб'єктивного трактування термінів та важкість необхідного дотримання вимог юридичної техніки під час розробки і прийняття нормативно-правових актів земельного законодавства та законодавства, пов'язаного з регулюванням нерухомості. Аналіз законодавчих актів свідчить, що значна частина з них виробляється 3 порушенням вимог законодавчої техніки, містить численні техніко-юридичні помилки. Найбільш типовими технічними недоліками законодавчих актів $\epsilon$ надмірна громіздкість їх текстів, невиправдане повторення й відтворення, декларативний характер та неконкретність формулювань правових положень, недотримання однозначності термінології, порушення системності, узгодженості юридичних норм i, як наслідок, - прогалини, протиріччя у правовому регулюванні суспільних відносин. Із метою усунення можливих колізій земельно-правової термінології на майбутнє під час розробки та прийняття нових нормативно-правових актів необхідно одночасно розробляти пропозиції щодо внесення змін до чинних нормативно-правових актів. Сьогодні гуманітарні і природничі (точні) науки стикаються й перетинаються в єдність наукового знання, породжуючи міждисциплінарність, у контексті поданого дослідження єдиним шляхом майбутнього розвитку земельно-цивілістичних відносин у якісно нову площину, вирішуючи проблематику теоретичного і практичного характеру.

\section{Література}

1. Каракаш І. Співвідношення буденного і соціального розуміння власності. Альманах права. Правовий світогляд: людина і право. 2014. Вип. 5. С. 431-437.

2. Суханов Е. Лекции о праве собственности М.: Юрид. лит. 1991. 240 с.

3. Скловский К. Собственность в гражданском праве. Москва : Статут, 2010. 836 с.

4. Цивільний кодекс України від 16 січня 2003 року. Відомості Верховної Ради України. 2003. № 40-44. Ст. 356.

5. Латиев А.Н. Вещанье права в гражданском праве: понятие и особенности правового режима : дис ... канд. юрид. наук : 12.00.06. Екатеринбург, 2004. 211 с.

6. Ріпенко А. Земельні ділянки та інші нерухомі речі як правові абстракції Форум права. 2013. № 1. С. 822-830.

7. Розенберг Д. Терминологический словарь. Университет Рутжерс (США), 2000.

8. Кулагин М. Предпринимательство и право: опыт Запада / М. Кулагин; под ред. проф. Е. Суханова. Москва : Дело, 1992. С. 110-115.

9. Павлов К. Диференціація об'єктів нерухомості в міжнародному вимірі. Economic journal of Lesia Ukrainka Eastern European National University. 2016. № 3. C. 12-18.

10. Про державну реєстрацію речових прав на нерухоме майно та їх обтяжень : Закон України від 1 липня 2004 року URL: http://zakon4.rada.gov.ua/.

Шматько Г. І., аспірант кафедри аграрного, земельного та екологічного права Національного університету «Одеська юридична академія» 